\title{
Manure Application Affects Soil Bacterial Community Structure in the Maize-wheat Rotation System of North China Plain
}

Gaoyuan Liu

Henan Academy of Agricultural Sciences

Ailing He

Henan Academy of Agricultural Sciences

Jun Du

Henan Academy of Agricultural Sciences

Huanhuan Yang

Henan Academy of Agricultural Sciences

Zhanping Yang

Henan Academy of Agricultural Sciences

Yuting Zhang ( $\nabla$ zhytsj@sohu.com )

Institute of Plant Nutrition and Environmental Resources, Henan Academy of Agricultural Sciences, Zhengzhou 450002, China.

\section{Research Article}

Keywords: maize-wheat rotation experiment, fertiliser-N plus manure input, conventional fertilisation

Posted Date: January 29th, 2021

DOl: https://doi.org/10.21203/rs.3.rs-153767/v1

License: (c) (1) This work is licensed under a Creative Commons Attribution 4.0 International License. Read Full License 


\section{Abstract}

A 2-year maize-wheat rotation experiment was conducted to clarify the characteristics of soil bacterial community under reduced fertiliser- $\mathrm{N}$ application rate on the North China Plain. Treatments were conventional fertilisation (CF), $80 \%$ fertiliser-N input $(80 \% \mathrm{~N})$ and $80 \%$ fertiliser-N plus manure input $(80 \% \mathrm{NM})$ in the wheat season, while the fertilisation regimes of previous maize were consistent. Results showed that $80 \% \mathrm{NM}$ increased wheat ear $\cdot \mathrm{m}^{-2}$ and 1,000 -grain weight by $5.1 \%$ and $7.5 \%$, and it also increased soil $\mathrm{C} / \mathrm{N}$ ratio (by $29.1 \%$ ) and dissolved organic $\mathrm{N}$ content (by $41.6 \%$ ), compared with $\mathrm{CF}$, although the difference in crop yields between treatments was not significant. Values of soil bacterial adiversity parameters (observed species, chao1 estimator, evenness and Shannon's diversity index) were improved under $80 \% \mathrm{NM}$, but not under $80 \% \mathrm{~N}$. Compared with $\mathrm{CF}, 80 \% \mathrm{NM}$ increased the abundance of phyla Firmicutes and Gemmatimonadetes but decreased the abundance of phylum Acidobacteria. Redundancy analysis indicated that organic $\mathrm{C}$, dissolved organic $\mathrm{N}$ and $\mathrm{C} / \mathrm{N}$ ratio were major environment variables affecting the distribution of bacterial phyla. These results suggest that manure application can improve soil fertility and productivity under reduced fertiliser-N application rate.

\section{Introduction}

Nitrogen fertiliser has been greatly used to enhance crop yields and plays a major role in global food security ${ }^{1}$. Less than $50 \%$ of applied $\mathrm{N}$ fertiliser are used by crops but $25 \%$ are emitted to the atmosphere and $20 \%$ are discharged to the aquatic system, which result in greenhouse effect and groundwater pollution ${ }^{2}$. Strategies for fertiliser-N reduction have been widely applied in the agricultural practices. Manure application is the most important among fertilisation regimes, because it not only enhances nutrient use efficiency and the qualities of agricultural products, but also improves soil properties ${ }^{3,4}$.

Microorganisms play a critical role in driving nutrient cycling in the soils ${ }^{5}$, where their community are obviously affected by fertilisation regimes ${ }^{6,7}$. Generally, manure application usually increases microbial biomass and activities, whereas chemical fertiliser has relatively less effect on microbial biomass than manure ${ }^{8,9}$. Fertilisation regimes also result in microbial community shifts in the soils ${ }^{8,10}$. In addition, microbial community diversity and composition also vary with tillage measures, because these measures change the soil properties ${ }^{11,12}$. Therefore, the effects of agricultural practices on microorganisms still need further study in soils, especially fertilisation regimes.

The maize (Zea mays L.) and wheat (Triticum aestivum L.) rotation is a common rotation system on the North China Plain (NCP), where produces about $25 \%$ of China's food. Under this system, intensive tillage and excessive fertiliser-N use may not have a large impact on crop yields but can notably decrease $\mathrm{N}$ use efficiency ${ }^{13}$. Excessive fertiliser- $\mathrm{N}$ use has caused soil acidification and groundwater pollution ${ }^{14,15}$. With the maize-wheat rotation system, we consequently conducted a 2-year field experiment under reduced fertiliser-N application rate. The objectives of this study were to: (i) ascertain the changes in crop yields 
and soil properties, (ii) quantify soil bacterial community diversity and composition, and (iii) determine the relationship between bacterial community composition and environment variables.

\section{Materials And Methods}

Experiment site. The experiment was conducted from 2017 to 2018 at the Duqu Agricultural Technology Extension Station $\left(33^{\circ} 47^{\prime} \mathrm{N}, 113^{\circ} 49^{\prime} \mathrm{E}\right)$, Luohe city, Henan province, China. The altitude of experiment site is $80 \mathrm{~m}$. Annual rainfall is $750-850 \mathrm{~mm}$, and mean annual temperature is $14.6^{\circ} \mathrm{C}$. Soil taxonomy is a Typic Dystruderts, which belongs to Vertisols in USDA. The tillage layer is concentrated at $0-20 \mathrm{~cm}$ depth band. Before this study, the soil properties at $0-20 \mathrm{~cm}$ depth band were: organic $\mathrm{C}(\mathrm{OC}) 8.6 \mathrm{~g} \cdot \mathrm{kg}^{-1}$, total N (TN) $0.64 \mathrm{~g} \mathrm{~kg}^{-1}$, available P (AP) $5.24 \mathrm{mg} \cdot \mathrm{kg}^{-1}$, available $\mathrm{K} 143.1 \mathrm{mg} \cdot \mathrm{kg}^{-1}, \mathrm{pH} 7.23$.

Experiment design. Treatments were conventional fertilisation (CF), $80 \%$ fertiliser- $\mathrm{N}$ input $(80 \% \mathrm{~N}$ ) and (iii) $80 \%$ fertiliser-N plus manure input ( $80 \% \mathrm{NM}$ ) in the wheat season, while the fertilisation regimes of previous maize were consistent. Each treatment was replicated four times randomly distributed in the field, with a plot size of $5 \times 6 \mathrm{~m}^{2}$. Detailed fertilisation and field management were shown in Table 1 . Manure (pig manure compost) nutrient contents were OC $21.4 \%$, TN $1.4 \%$, total P $1.0 \%$ and total K $1.2 \%$. Manure application rate was calculated based on $20 \%$ of net $\mathrm{N}$ rate. In the maize season, like local farmers, fertilisation and sowing were simultaneously implemented with an integrated machine. Before wheat sowing, $70 \%$ of fertiliser- $\mathrm{N}$ rate and manure were applied under $80 \% \mathrm{NM}$, and $70 \%$ of fertiliser-N rate was applied under both treatments of $80 \% \mathrm{~N}$ and CF. The reminding fertiliser- $\mathrm{N}$ rate was evenly broadcasted on the soil surface as top dressing at the jointing stage. The sowing densities of maize and wheat were 0.07 and 2.32 million plants per hectare, respectively. Agricultural practices kept consistent with local farmers.

Table 1. Fertilisation application rate $\left(\mathrm{kg} \mathrm{hm}^{-2}\right)$ and field management

\begin{tabular}{|lllllllll|}
\hline Treatment & \multicolumn{9}{l}{ Maize } & \multicolumn{3}{l}{ Wheat } & \multicolumn{2}{c}{ Straw return } \\
\cline { 2 - 7 } & $\mathrm{N}$ & $\mathrm{P}_{2} \mathrm{O}_{5}$ & $\mathrm{~K}_{2} \mathrm{O}$ & $\mathrm{N}$ & $\mathrm{P}_{2} \mathrm{O}_{5}$ & $\mathrm{~K}_{2} \mathrm{O}$ & Manure & \\
\hline $\mathrm{CF}$ & 240 & 90 & 90 & 240 & 120 & 90 & $/$ & Yes \\
\hline $80 \% \mathrm{~N}$ & 240 & 90 & 90 & 192 & 120 & 90 & $/$ & Yes \\
\hline $80 \% \mathrm{NM}$ & 240 & 90 & 90 & 192 & 120 & 90 & 4500 & Yes \\
\hline
\end{tabular}

Sample collection and analyses. During maize harvest, 2 rows of plant samples from each plot were collected and air-dried to determine ear. $\mathrm{hm}^{-2}$, grain number per ear and 100-grain weight. During wheat harvest, $2 \mathrm{~m}^{2}$ plant samples from each plot were collected and air-dried to determine ear $\cdot \mathrm{m}^{-2}$, grain 
number per ear and 1,000-grain weight. Crop yield in each plot was determined at a $12 \%$ moisture content. After wheat harvest in 2019 , five samples at $0-20 \mathrm{~cm}$ soil depth from each plot were collected with an auger and mixed to give a bulk sample. Stone-free samples were thoroughly homogenized and divided into two-part subsample: some subsamples were air-dried and screened ( $0.25 \mathrm{~mm}$ mesh) to determine nutrient contents and $\mathrm{pH}$, and the others were stored at $-20^{\circ} \mathrm{C}$ for microbial analysis.

The contents of OC, TN, inorganic $\mathrm{N}$ (including $\mathrm{N}$ and $\mathrm{N}$ ) and AP in soils were determined according to the methods described by Bao ${ }^{16}$. Concentration of total dissolved $N(T D N)$ was determined using an ultraviolet spectrophotometer (U-3900H, Hitachi, Japan) by an alkaline potassium persulfate oxidation method. Dissolved organic N (DON) was calculated as the difference between TDN and IN readings ${ }^{17}$. pH was measured in a soil water suspension ( $10 \mathrm{~g}$ soil to $25 \mathrm{~mL}$ deionized water) after shaking $1 \mathrm{~h}$ at 180 $\mathrm{r} \cdot \mathrm{min}^{-1}$ on a reciprocal shaker.

Total DNA were extracted $0.5 \mathrm{~g}$ of fresh soil using an E. Z. N. A. Soil DNA Kit (Omega Bio-tek, Norcross, GA, USA) according to the manufacturer's instruction. Isolated DNA was electrophoresed on $1.0 \%$ of agarose gels for quality check and quantified using a Nanodrop Spectrophotometer (Nanodrop 2000, Thermo Fisher Scientific, USA) for purity. The V3-V4 region of 16S rRNA gene was amplified by PCR using the primer 388F (5'-ACTCCTACGGGAGGCAGCAG-3') and 806R (5'-GGACTACHVGGGTWTCTAAT-3') ${ }^{18}$. In the first-round of PCR, the reaction mixtures $(20 \mu \mathrm{L})$ contained $4.0 \mu \mathrm{L}$ of $5 \times$ Fastpfu Buffer, $2.0 \mu \mathrm{L}$ of 2.5 $\mathrm{mmol} \cdot \mathrm{L}^{-1} \mathrm{dNTPs}, 0.8 \mu \mathrm{L}$ of $5 \mu \mathrm{mol} \cdot \mathrm{L}^{-1}$ each primer, $0.4 \mu \mathrm{L}$ of FastPfu DNA Polymerase (Shanghai, China), $10 \mathrm{ng}$ of template DNA, $0.2 \mu \mathrm{L}$ of $20 \mathrm{mg} \cdot \mathrm{L}^{-1}$ bovine serum albumin (BSA). Purified PCR products were sequenced using an Illumina Miseq system.

Statistical analyses. Sequence data were processed using QIIME2. All sequence reads were trimmed and assigned to each sample based on their barcodes. Similar sequences were clustered into operational taxonomic units (OTUs) using a 97\% identity threshold with mothur v. 1.30.1. Aligned 16S rRNA gene sequences were used for a chimera check using UCHIME algorithm. The representative sequence for each OTU was picked and its taxonomic affiliation was assigned by the Ribosomal Database Project classifier v. 2.2. against the Silva $16 \mathrm{~S}$ rRNA database. Each sample was rarefied to the same number of reads for the analyses of bacterial a-diversity.

The differences in yields were analyzed using one-way ANOVA with SPSS v. 21.0, as well as in bacterial community abundance and physicochemical properties. Change in bacterial community structure was evaluated by PCOA based on the UniFrac distances. The significance of weighted PCoA scores was assessed by per MANOVA. Hierarchical cluster analysis (HCA) was performed using the 'hclust' function with an average linkage algorithm in the $R$ (v. 3.6.0) statistical package. The analyses of unique and shared OTUs were according to the method described by Zhao et al. ${ }^{19}$. Redundancy analysis (RDA) was performed using functions in the Vegan package (v. 2.4-5) of $\mathrm{R}^{20}$. The correlation between environment variables and bacterial community composition was determined by Pearson's Correlation Coefficient using the $\mathrm{R}$. 


\section{Results And Discussion}

Crop yields and yield components. The results of maize yields and yield components were shown in Supplementary Table S1, but no significant differences were observed between fertilisation treatments. The differences in wheat yields between treatments were not significant, but wheat yield components were obviously affected by fertilisation treatments (Table 2 ). Compared with $\mathrm{CF}$, ear $\cdot \mathrm{m}^{-2}$ and 1,000 -grain weight under $80 \%$ NM were increased by $5.1 \%$ (by $5.9 \%$ in 2018 and $4.2 \%$ in 2019 ) and $7.5 \%$ (by $7.6 \%$ in 2018 and $7.3 \%$ in 2019), respectively. This result may be due to manure application improves root growth environment, thus increasing total wheat tillers and nutrient absorption ${ }^{21}$. However, 1,000-grain weight under $80 \% \mathrm{~N}$ was decreased by $5.4 \%$ in 2018 and $4.7 \%$ in 2019 , respectively (Table 2 ).

\section{Table 2. Wheat yields and yield components under different treatments}

\begin{tabular}{|clllll|}
\hline Year & Treatment & $\begin{array}{l}\text { Yield }\left(\mathrm{kg} \cdot \mathrm{hm}^{-}\right. \\
\text {2) }\end{array}$ & Ear $\cdot \mathrm{m}^{-2}$ & $\begin{array}{l}\text { Grain number per } \\
\text { ear }\end{array}$ & $\begin{array}{l}1,000 \text {-grain weight } \\
(\mathrm{g})\end{array}$ \\
\hline 2018 & $\mathrm{CF}$ & $5,784 \pm 105 \mathrm{ab}$ & $462.2 \pm 10.4 \mathrm{~b}$ & $42.8 \pm 3.0 \mathrm{a}$ & $40.7 \pm 0.9 \mathrm{~b}$ \\
& $80 \% \mathrm{~N}$ & $5,709 \pm 169 \mathrm{~b}$ & $469.0 \pm 15.9 \mathrm{ab}$ & $43.2 \pm 1.8 \mathrm{a}$ & $38.5 \pm 1.2 \mathrm{c}$ \\
& $80 \% \mathrm{NM}$ & $6,037 \pm 202 \mathrm{a}$ & $489.4 \pm 13.7 \mathrm{a}$ & $43.6 \pm 2.5 \mathrm{a}$ & $43.8 \pm 1.1 \mathrm{a}$ \\
\hline 2019 & $\mathrm{CF}$ & $5,957 \pm 182 \mathrm{ab}$ & $481.1 \pm 7.2 \mathrm{~b}$ & $43.6 \pm 2.3 \mathrm{a}$ & $41.0 \pm 0.2 \mathrm{~b}$ \\
& $80 \% \mathrm{~N}$ & $5,515 \pm 203 \mathrm{~b}$ & $479.0 \pm 8.7 \mathrm{~b}$ & $42.4 \pm 3.6 \mathrm{a}$ & $39.1 \pm 0.5 \mathrm{c}$ \\
\hline & $80 \% \mathrm{NM}$ & $6,209 \pm 254 \mathrm{a}$ & $498.6 \pm 4.1 \mathrm{a}$ & $44.1 \pm 3.0 \mathrm{a}$ & $44.1 \pm 0.3 \mathrm{a}$ \\
\hline
\end{tabular}

Note: Values (means $\pm S D, n=4$ ) within the same column followed by different letters represent significant differences $(P<0.05)$.

Soil chemical properties. Among the measured indicators, those were no significant differences between different fertilisation treatments, except $\mathrm{C} / \mathrm{N}$ ratio, DON and AP contents (Table 3). Soil $\mathrm{C} / \mathrm{N}$ ratio and DON content were increased by $29.1 \%$ and $41.6 \%$ under $80 \% \mathrm{NM}$ than those under $\mathrm{CF}$, respectively. The result can be explained as manure application increased crop residues into the soil, and hence promote $\mathrm{C}$ accumulation and the concentration of dissolved nutrients ${ }^{22}$. For AP content, it was an $8.4 \%$ increase under $80 \% \mathrm{~N}$ when compared with CF. This result has been described by Akinnifesi et al. ${ }^{23}$, who attributed to a synergistic effect between $\mathrm{N}$ and $\mathrm{P}$ absorbed by crops. However, no significant difference in AP was found between $80 \% \mathrm{NM}$ and $\mathrm{CF}$. 
Table 3. Effects of different fertilisation treatments on soil chemical properties

\begin{tabular}{|c|c|c|c|}
\hline \multirow[t]{2}{*}{ Item } & \multicolumn{3}{|l|}{ Treatment } \\
\hline & CF & $80 \% \mathrm{~N}$ & $80 \% \mathrm{NM}$ \\
\hline$O C\left(g \cdot k^{-1}\right)$ & $9.92 \pm 0.91 a b$ & $9.81 \pm 0.63 b$ & $11.8 \pm 1.13 a$ \\
\hline $\mathrm{TN}\left(\mathrm{g} \cdot \mathrm{kg}^{-1}\right)$ & $0.72 \pm 0.20 \mathrm{a}$ & $0.66 \pm 0.12 a$ & $0.76 \pm 0.24 a$ \\
\hline $\mathrm{C} / \mathrm{N}$ ratio & $14.1 \pm 1.4 b$ & $16.2 \pm 0.7 a b$ & $18.2 \pm 1.1 \mathrm{a}$ \\
\hline IN $\left(\mathrm{mg} \cdot \mathrm{kg}^{-1}\right)$ & $78.4 \pm 6.4 a$ & $76.4 \pm 10.9 a$ & $82.5 \pm 8.7 a$ \\
\hline DON $\left(\mathrm{mg} \cdot \mathrm{kg}^{-1}\right)$ & $7.53 \pm 0.42 b$ & $7.07 \pm 0.58 b$ & $10.66 \pm 0.76 a$ \\
\hline $\operatorname{AP}\left(\mathrm{mg} \cdot \mathrm{kg}^{-1}\right)$ & $7.37 \pm 0.13 b$ & $7.97 \pm 0.18 a$ & $7.63 \pm 0.19 a b$ \\
\hline $\mathrm{pH}$ & $7.07 \pm 0.12 a$ & $6.95 \pm 0.11 \mathrm{a}$ & $7.11 \pm 0.14 a$ \\
\hline
\end{tabular}

Note: Values (means $\pm S D, n=4)$ within the same row followed by different letters represent significant differences $(P<0.05)$ between treatments.

Bacterial community diversity and structure. A total of 98,948 high quality and chimera-free reads were obtained by MiSeq sequencing of $16 \mathrm{~S}$ rRNA gene amplicon from 12 soil samples. After equalizing the sampling effort, 8,376 sequences from each sample were retained for analyses. Both sequencing and QPCR data showed that the relative abundance of bacterial community was more than $98.5 \%$. The bacterial a-diversity parameters were listed in Table 4. In general, the reduction in fertiliser-N application rate increased bacterial a-diversity, compared with CF. Meanwhile, $80 \% \mathrm{NM}$ significantly increased obvious species, chao1 estimator and Shannon's diversity index. This is related to manure application increase exogenous-C input, such as fine non-protected $C$, light fraction $C$ and heavy fraction $C$, which improve $C$ availability and stimulate microbial growth ${ }^{24,25}$.

\section{Table 4. Bacterial a-diversity under different fertilisation treatments}




\begin{tabular}{|llll|}
\hline Parameter & \multicolumn{2}{l|}{ Treatment } & \\
\cline { 2 - 4 } & $\mathrm{CF}$ & $80 \% \mathrm{~N}$ & $80 \% \mathrm{NM}$ \\
\hline Coverage & $0.98 \pm 0.01 \mathrm{a}$ & $0.99 \pm 0.00 \mathrm{a}$ & $0.98 \pm 0.01 \mathrm{a}$ \\
\hline Observed species & $1072 \pm 18 \mathrm{~b}$ & $1092 \pm 26 \mathrm{~b}$ & $1141 \pm 12 \mathrm{a}$ \\
\hline Chao1 estimator & $2,154 \pm 24 \mathrm{~b}$ & $2,182 \pm 18 \mathrm{ab}$ & $2,218 \pm 19 \mathrm{a}$ \\
\hline Evenness & $0.39 \pm 0.02 \mathrm{a}$ & $0.39 \pm 0.01 \mathrm{a}$ & $0.41 \pm 0.02 \mathrm{a}$ \\
\hline Shannon's diversity index & $6.69 \pm 0.02 \mathrm{~b}$ & $6.71 \pm 0.03 \mathrm{~b}$ & $6.78 \pm 0.02 \mathrm{a}$ \\
\hline
\end{tabular}

Note: Values (means $\pm S D, n=4$ ) within the same row followed by different letters represent significant differences $(P<0.05)$.

PCoA and HCA were used to reveal differences in bacterial community structure between treatments (Fig. 1). PCoA showed that fertilisation treatments contributed $44.7 \%$ of total variation in the first principal coordinate axis (Fig. 1A), where bacterial community structure was similar under CF and $80 \% \mathrm{~N}$ but became significantly $(P<0.01)$ different between $80 \% \mathrm{NM}$ and CF. The result was confirmed by HCA, such as the treatments of $80 \% \mathrm{NM}$ were roughly separated from those of $\mathrm{CF}$, whereas the treatments of $80 \% \mathrm{~N}$ and CF were grouped together (Fig. 1B). This result can be explained that manure application increases phospholipid fatty acid content for bacteria ${ }^{8}$. Meanwhile, the increases in $\mathrm{C}$ quantity and availability have a priming effect on shifts in microbial community structure ${ }^{26}$.

Bacterial community composition. High-quality 16S rRNA gene sequences were clustered into 13,420 OTUs, with 1,054-1,156 OTUs each sample. The predominant phyla across all samples were Proteobacteria, Actinobacteria, Acidobacteria, Chloroflexi, Firmicutes, Bacteroidetes, Gemmatimonadetes and Rokubacteria (> 1\%), accounting for $88.7 \%$ of gene sequences in each sample (Fig. 2A). Compare to $\mathrm{CF}$, the abundance of phyla Firmicutes and Gemmatimonadetes under $80 \% \mathrm{NM}$ were increased by $62.4 \%$ and $50.6 \%$, respectively (Fig. 2A). The phyla Firmicutes and Gemmatimonadetes belong to typical copiotrophic microorganisms and tend to grow fast in environments with rich nutrients, particularly organic nutrients ${ }^{20}$, and they play an important role in soil $\mathrm{C}$ and $\mathrm{N}$ cycle ${ }^{27,28}$. However, the abundance of phylum Acidobacteria under $80 \% \mathrm{NM}$ was decreased by $39.3 \%$ when compared with CF (Fig. 2A). This result may be due to the fact that most members of Acidobacteria were suggested to be slow-growing oligotrophic microorganisms ${ }^{29}$, and they are more adapted to nutrient-limited soil environment ${ }^{30}$. No significant differences in bacterial community composition were observed between $80 \% \mathrm{~N}$ and CF (Fig. 2A). 
The number of unique OTUs under $\mathrm{CF}, 80 \% \mathrm{~N}$ and $80 \% \mathrm{NM}$ accounted for $10.2 \%, 10.7 \%$ and $15.9 \%$ of total observed OTUs, respectively, and the majority (41.2\%-58.6\%) of unique OTUs were the phyla Acidobacteria and Firmicutes (Fig. 2B). 812 OTUs were shared among treatments, which accounted for $55.9 \%$ of total observed OTUs, and they were the phyla Proteobacteria, Actinobacteria, Acidobacteria and Chloroflexi (Fig. 2B).

Relationship between environment variables and bacterial community composition. Fig. 3 showed the relationship between environment variables and the distribution of bacterial phyla. RDA1 (horizontal) and RDA2 (vertical) axis explained $82.0 \%$ of total variability. RDA1 axis was significantly $(P<0.05)$ correlated with $\mathrm{OC}, \mathrm{DON}$ and $\mathrm{C} / \mathrm{N}$ ratio, which explained $67.9 \%$ of total variability. RDA2 axis was strongly associated with AP and IN, which explained $8.8 \%$ of total variability. According to the result of RDA, OC, DON and $\mathrm{C} / \mathrm{N}$ ratio were major environment variables affecting the distribution of bacterial phyla.

Cluster heatmap was used to show the correlation between environment variables and the abundance of bacterial phyla (Fig. 4). A significant $(P<0.05)$ positive correlation could be found between phyla Firmicutes and Gemmatimonadetes and $\mathrm{OC}$ or $\mathrm{C} / \mathrm{N}$ ratio, and between phylum Gemmatimonadetes and DON. However, there was a significant $(P<0.05)$ negative correlation between phylum Acidobacteria and OC.

Changes in environment variables regulate shifts in microbial community composition in soils ${ }^{20}$. In our study, OC, DON and $\mathrm{C} / \mathrm{N}$ ratio were the major environment variables affecting bacterial community composition (Figs. 3 and 4). Nutrient availability, particularly $\mathrm{C}$ and $\mathrm{N}$ have been considered as the main factors driving shift in microbial community, since soil attributes may select some keystone species over others $^{20,31}$.

\section{Conclusions}

In the maize-wheat rotation system, fertiliser- $\mathrm{N}$ plus manure input increased wheat ear $\cdot \mathrm{m}^{-2}$ and 1,000 grain weight under reduced fertiliser- $\mathrm{N}$ application rate, and it also increased the soil $\mathrm{C} / \mathrm{N}$ ratio and dissolved organic $\mathrm{N}$ content, although it did not affect crop yields. For bacterial community, manure application improved bacterial diversity and increased the abundance of copiotrophic bacteria but decreased the abundance of oligotrophic bacteria. These results suggest that in the maize-wheat rotation system, manure application is more conducive to promoting soil fertility and productivity under reduced fertiliser-N application rate.

\section{Declarations}




\section{Acknowledgements}

We thank to the staff in Duqu Agricultural Technology Extension Station for their sampling and are also very grateful to Researcher Dejun Bao from Henan Academy of Agricultural Sciences for his guidance during sampling. This work was financially supported by the Henan Postdoctoral Science Foundation (201903052) and by the National Key Research and Development Program (2018YFD0200605).

\section{Author Contributions}

Yuting Zhang and Zhanping Yang designed the study; Gaoyuan Liu, Ailing He and Jun Du performed the experiments; Gaoyuan Liu and Huanhuan Yang analysed the data and wrote the manuscript. All authors reviewed the manuscript.

\section{References}

1 Galloway, J. N. et al. Transformation of the nitrogen cycle: recent trends, questions, and potential solutions. Science320, 889-892, doi:10.1126/science.1136674 (2008).

2 Cameron, K. C., Di, H. J. \& Moir, J. Nitrogen losses from the soil/plant system: A review. Ann. Appl. Biol.162, 145-173, doi:10.1111/aab.12014 (2013).

3 Abbasi, M. K., Tahir, M. M. \& Rahim, N. Effect of N fertilizer source and timing on yield and N use efficiency of rainfed maize (Zea mays L.) in Kashmir-Pakistan. Geoderma195-196, 87-93, doi:org/10.1016/j.geoderma.2012.11.013 (2013).

4 Hlisnikovský, L., Vach, M., Abrhám, Z., Mensik, L. \& Kunzová, E. The effect of mineral fertilisers and farmyard manure on grain and straw yield, quality and economical parameters of winter wheat. Plant Soil Environ.66, 249-256, doi:10.17221/60/2020-PSE (2020).

5 Liu, Y. R. et al. New insights into the role of microbial community composition in driving soil respiration rates. Soil Biol. Biochem.118, 35-41, doi:10.1016/j.soilbio.2017.12.003 (2018).

6 Dong, W. Y. et al. Changes in soil microbial community composition in response to fertilization of paddy soils in subtropical China. Appl. Soil Ecol.84, 140-147, doi:10.1016/j.apsoil.2014.06.007 (2014).

7 Peng, S. et al. Bacteria play a more important role than nutrients in the accumulation of tetracycline resistance in manure-treated soil. Biol. Fert. Soils52, 655-663, doi:10.1007/s00374-016-1105-9 (2016).

8 Zhang, Q. C. et al. Chemical fertilizer and organic manure inputs in soil exhibit a vice versa pattern of microbial community structure. Appl. Soil. Ecol.57, 1-8, doi:10.1016/j.apsoil.2012.02.012 (2012).

9 Stevlikova, T., Vjatráková, J., Javoreková, S. \& Mateová, S. Effect of land management without farmyard manure application on the amount and the activity of soil microbial biomass. Plant Soil Environ.49, 352-358, doi:10.1046/j.1365-3059.2003.00873.x (2003). 
10 Marschner, P., Kandeler, E. \& Marschner, B. Structure and function of the soil microbial community in a long-term fertilizer experiment. Soil Biol. Biochem.35, 453-461, doi:10.1016/S0038-0717(02)00297-3 (2003).

11 Treseder, K. K. Nitrogen additions and microbial biomass: A meta-analysis of ecosystem studies. Ecol. Lett.11, 1111-1120, doi:10.1111/j.1461-0248.2008.01230.x (2008).

12 Geisseler, D. \& Scow, K. M. Long-term effects of mineral fertilizers on soil microorganisms - A review. Soil Biol. Biochem.75, 54-63, doi:10.1016/j.soilbio.2014.03.023 (2014).

13 Yang, X. L. et al. Optimising nitrogen fertilisation: A key to improving nitrogen-use efficiency and minimising nitrate leaching losses in an intensive wheat/maize rotation (2008-2014). Field Crop. Res.206, 1-10, doi:10.1016/j.fcr.2017.02.016 (2017).

14 Guo, J. H. et al. Significant acidification in major Chinese croplands. Science327, 1008-1010, doi:10.1126/science.1182570 (2010).

15 Zhang, W. F. et al. New technologies reduce greenhouse gas emissions from nitrogenous fertilizer in China. P. Natl. Acad. Sci. USA.110, 8375-8380, doi:10.1073/pnas.1210447110 (2013).

16 Bao, S. D. Soil agrochemical analysis, 3rd Edition. (Beijing, China, 2005).

17 Jones, D. L., Shannon, D., V. Murphy, D. \& Farrar, J. Role of dissolved organic nitrogen (DON) in soil N cycling in grassland soils. Soil Biol. Biochem.36, 749-756, doi:10.1016/j.soilbio.2004.01.003 (2004).

18 Xu, N., Tan, G. C., Wang, H. Y. \& Gai, X. P. Effect of biochar additions to soil on nitrogen leaching, microbial biomass and bacterial community structure. Eur. J. Soil Biol.74, 1-8, doi:10.1016/j.ejsobi.2016.02.004 (2016).

19 Zhao, J. et al. Effects of organic-inorganic compound fertilizer with reduced chemical fertilizer application on crop yields, soil biological activity and bacterial community structure in a rice-wheat cropping system. Appl. Soil Ecol.99, 1-12, doi:10.1016/j.apsoil.2015.11.006 (2016).

20 Das, S., Jeong, S. T., Das, S. \& Kim, P. J. Composted cattle manure increases microbial activity and soil fertility more than composted swine manure in a submerged rice Paddy. Front. Microbiol.8, 1702-1702, doi:10.3389/fmicb.2017.01702 (2017).

21 Wang, X. J. et al. Impacts of manure application on soil environment, rainfall use efficiency and crop biomass under dryland farming. Sci. Rep.6, 20994, doi:10.1038/srep20994 (2016).

22 Meng, L., Ding, W. X. \& Cai, Z. C. Long-term application of organic manure and nitrogen fertilizer on $\mathrm{N}_{2} \mathrm{O}$ emissions, soil quality and crop production in a sandy loam soil. Soil Biol. Biochem.37, 2037-2045, doi:10.1016/j.soilbio.2005.03.007 (2005). 
23 Akinnifesi, F. K., Makumba, W., Sileshi, G., Ajayi, O. C. \& Mweta, D. Synergistic effect of inorganic N and $P$ fertilizers and organic inputs from Gliricidia sepium on productivity of intercropped maize in Southern Malawi. Plant Soil294, 203-217, doi:10.1007/s11104-007-9247-z (2007).

24 Zhong, W. H. et al. The effects of mineral fertilizer and organic manure on soil microbial community and diversity. Plant Soi/326, 511-522, doi:10.1007/s11104-009-9988-y (2010).

25 Liang, Q. et al. Effects of 15 years of manure and inorganic fertilizers on soil organic carbon fractions in a wheat-maize system in the North China Plain. Nutr. Cycl. Agroecosys.92, 21-33, doi:10.1007/s10705011-9469-6 (2012).

26 Zhao, Z. W. et al. Carbon and nitrogen availability in paddy soil affects rice photosynthate allocation, microbial community composition, and priming: combining continuous ${ }^{13} \mathrm{C}$ labeling with PLFA analysis. Plant Soil445, 137-152, doi:10.1007/s11104-018-3873-5 (2019).

27 Guo, Y. Q. et al. Natural revegetation of a semiarid habitat alters taxonomic and functional diversity of soil microbial communities. Sci. Total. Environ.635, 598-606, doi:10.1016/j.scitotenv.2018.04.171 (2018).

28 Ling, N. et al. Differential responses of soil bacterial communities to long-term $\mathrm{N}$ and $\mathrm{P}$ inputs in a semi-arid steppe. Geoderma292, 25-33, doi:10.1016/j.geoderma.2017.01.013 (2017).

29 Fierer, N. et al. Comparative metagenomic, phylogenetic and physiological analyses of soil microbial communities across nitrogen gradients. ISME J.6, 1007-1017, doi:10.1038/ismej.2011.159 (2012).

30 Zhang, Y. T. et al. Long-term and legacy effects of manure application on soil microbial community composition. Biol. Fert. Soils54, 269-283, doi:10.1007/s00374-017-1257-2 (2018).

31 Francioli, D. et al. Mineral vs. organic amendments: microbial community structure, activity and abundance of agriculturally relevant microbes are driven by long-term fertilization strategies. Front. Microbiol.7, 1446-1446, doi:10.3389/fmicb.2016.01446 (2016).

\section{Figures}


A

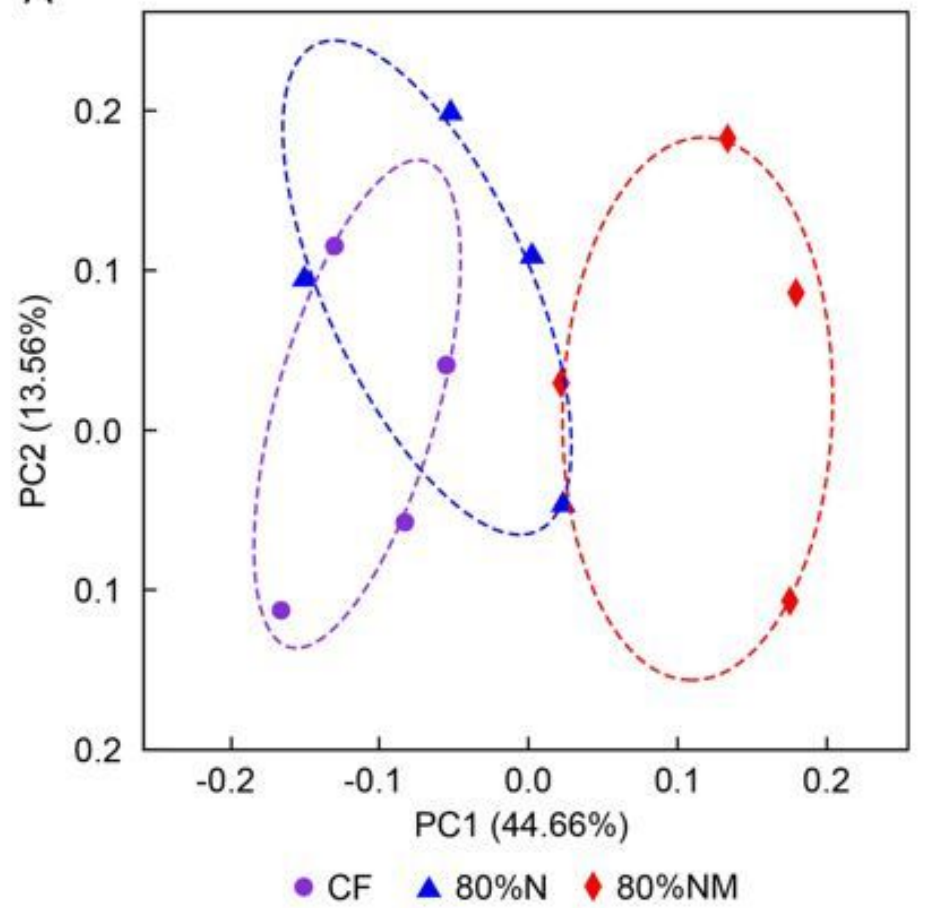

B

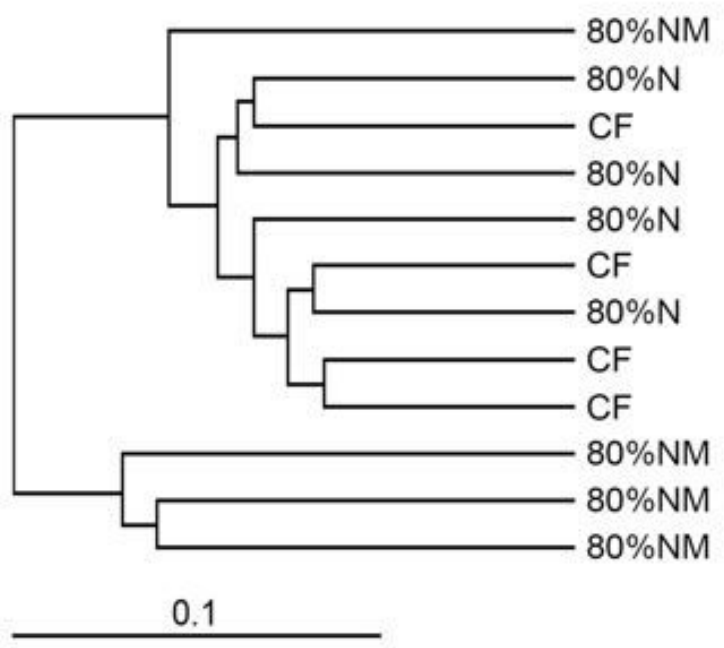

\section{Figure 1}

Soil bacterial community structure under different fertilisation treatments. A, PCoA score plot based on weighted UniFrac metrics; B, Clustering of soil bacteria based on the UniFrac distances.

A

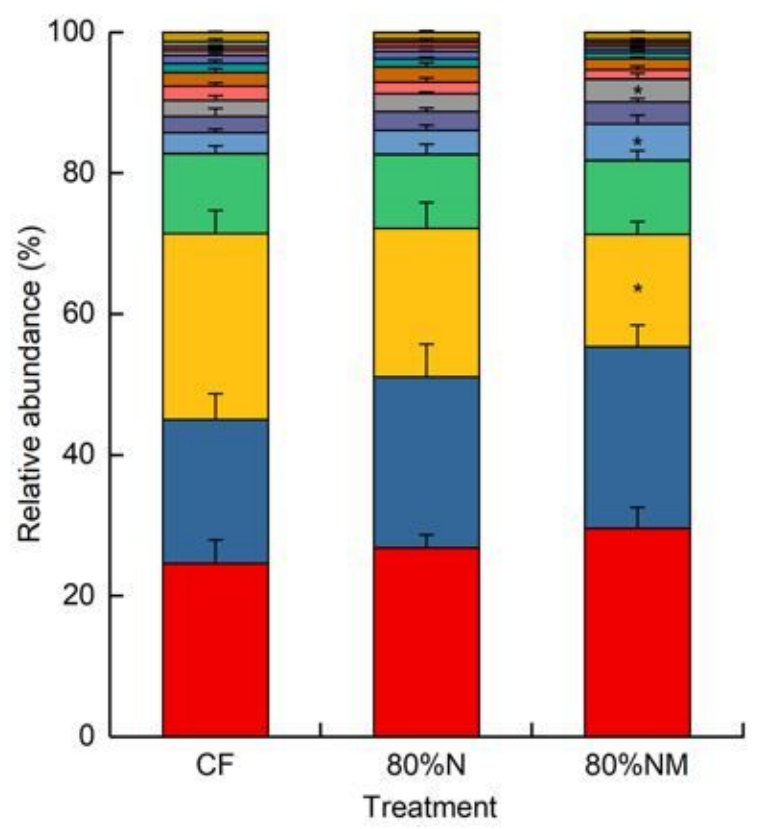

B

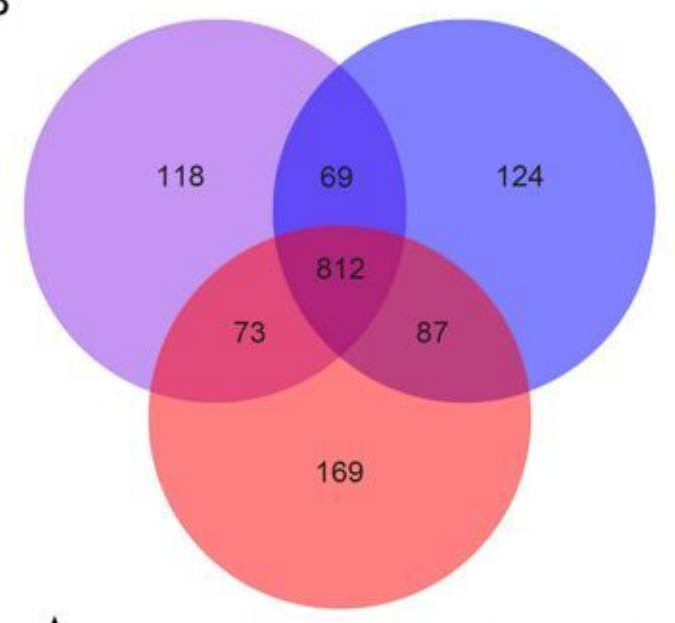

Others

Nitrospirae

Latescibacteria

Entotheonellaeota

Verrucomicrobia

Planctomycetes

Patescibacteria

Rokubacteria

Gemmatimonadetes

Bacteroidetes

Firmicutes

Chloroflexi

Acidobacteria

Actinobacteria

Proteobacteria

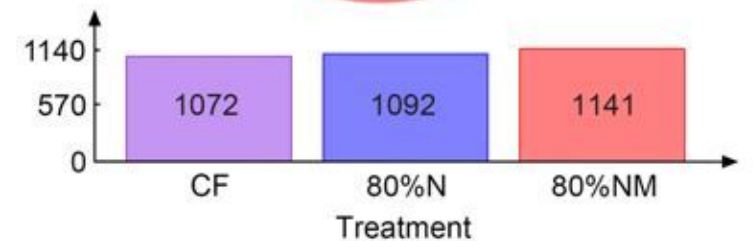

Figure 2 
The abundance of bacterial phyla and the number of unique and shared OTUs under different fertilisation treatments. A, Histogram showing the abundance of bacterial phyla, * indicates that the abundance of phylum is significantly different from $C F(P<0.05)$; $B$, Venn diagram showing the number of unique and shared OTUs.

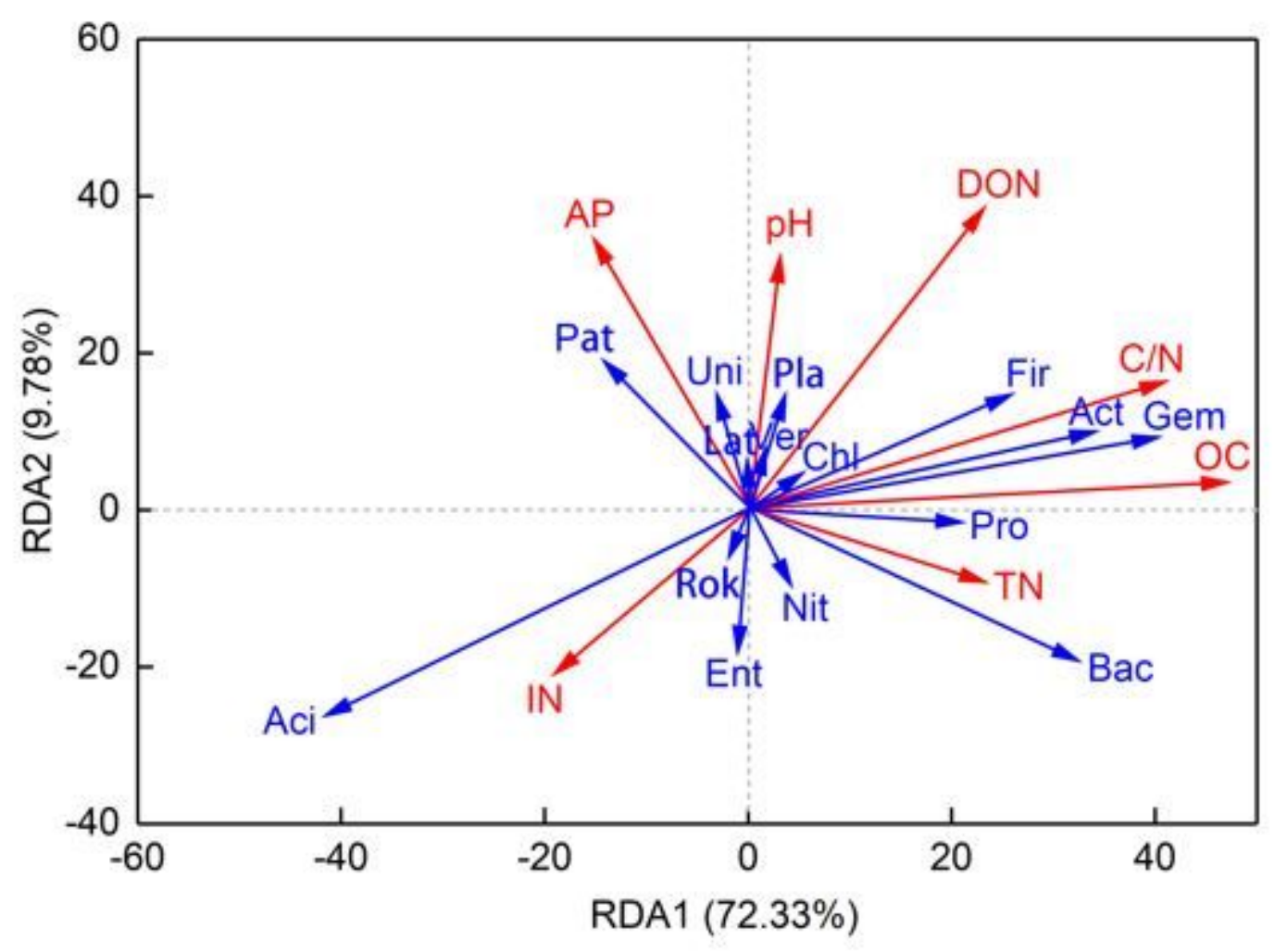

\section{Figure 3}

RDA between environmental variables and the distribution of bacterial phyla. The explanatory variables are indicated by different color arrows, i.e., environmental variables by red arrows and bacterial phyla by blue arrows. Pro, Proteobacteria; Act, Actinobacteria; Aci, Acidobacteria; Chl, Chloroflexi; Bac, Bacteroidetes; Gem, Gemmatimonadetes; Rok, Rokubacteria; Fir, Firmicutes; Pat, Patescibacteria; Pla, Planctomycetes; Ver, Verrucomicrobia; Ent, Entotheonellaeota; Lat, Latescibacteria; Nit, Nitrospirae; Uni, Unclassed bacteria. 


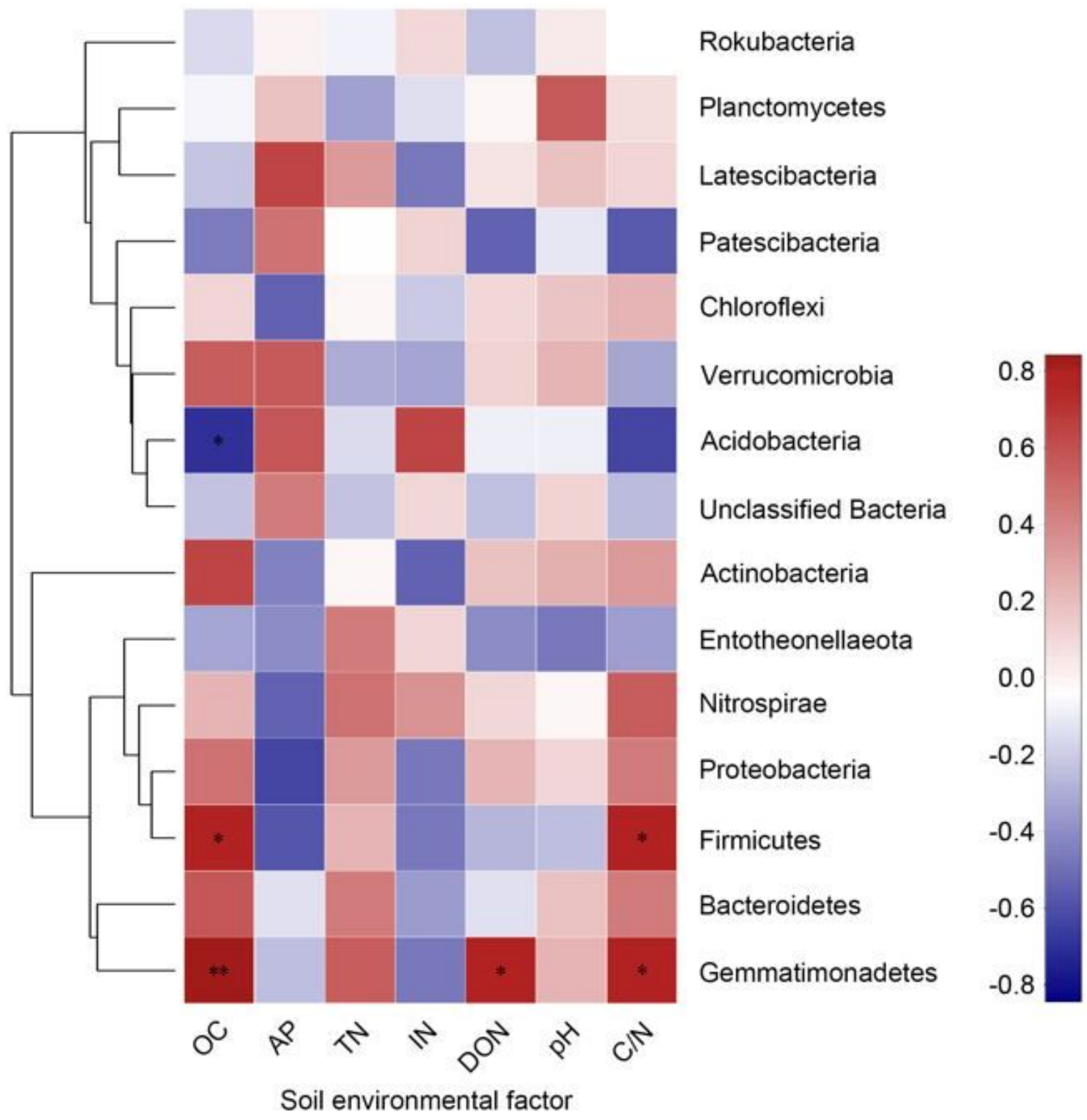

Figure 4

The correlation between environmental variables and the abundance of bacterial phyla. * and ** indicate significant correlation at $\mathrm{P}<0.05$ and $\mathrm{P}<0.01$, respectively.

\section{Supplementary Files}

This is a list of supplementary files associated with this preprint. Click to download.

- SupplementaryTableS1.docx 